\title{
Status of fish farming in Rivers State, Nigeria
}

\author{
Ibemere, I. F. / Ezeano, C. I.
}

\section{Abstract}

The study surveyed the status of fish farming in Rivers State of Nigeria Structured interview schedule questionnaires were used in sourcing informaion from 90 fish farmers randomly selected from nine local government area, with three local government each drawn from each agricultural zone of the state. Data oblained were analyzed using descriptive statistics. The findings revealed that majority (34.4\%) of the fish farmers were male and hetween the age range of 41-50 years. $31.1 \%$ of fish farmers cultured their fish in concrete fish tanks. The total mean anmual production of fishes were 41,000 metric tons, $38.9 \%$ of fish farmers practiced integrated fish farming, $72.2 \%$ of the framers practice only fish production; $58.9 \%$ of farmers sourced their information from friends/fellow farmers. In terms of water supply, $40.0 \%$ of farmers sourced their water supply from borehole, $36.6 \%$ use tilapia species as their fingerlings, $38.9 \%$ of farmers sourced their fingerlings from government hatchery $15.2 \%$ of farmers indicated that they suffer loss of tilapia, $54.4 \%$ farmers use partial harvest, $92.6 \%$ of farmers indicated irregular electricity supply as a major constraints to fish production. In order to facilitate the efficient operation of fish farming in the study area technical advice on pond construction and preparation, species selection and supply for stocking purposes and collection of relevani daia on aquaculture will help in the improvement of fish farming in the study area.

Keywords: Aquaculture, fish, Rivers State.

\section{Introduction}

$\mathrm{F}$

ish farming, although over 2000 years old started in Nigeria in the early 1950's first in Panyam Plateau state, the Onikan in Lagos and Umuna Okigwe in Imo State (Wokoma, 1986), the fish yields and desired impact of these government fish farms has not been as appreciable as was earlier intended. Until recently the popularization of fish farming remained largely within government circle. Several government policies attempted to improve fish farming. In 1980s the Directorate of Food, Road and Rural Infrastructure (DFRRI) introduced nationwide the homestead fish pond and hatchery construction projects. This gave rise to establishment of over 3,000 homestead fish ponds as well as hatcheries in each of the existing states of Nigeria (Satia, 1990; NEPAD, 2005).

Rivers state belongs to one of the coastal states in Niger Delta region of the country with vast potential for fish farming (Anyanwu et al., 2007). The state is characterized by various types of water bodies such as rivers, fresh and brackish water, creeks and estuaries as well as marine water bodies. This water bodies provide great opporiunitics for aquaculture. Fish farming in the state is rather means of capture fisheries which is the preoccupation of most riverine communities in the state. The need to increase food supply especially animals protein in Nigeria like in most third world countries gave rise to culture fishery activities in the state (Akinrotimi et al., 2007). In recent times, aquaculture has gained wide popularity. It has been identified as a rational way of augmenting the dwindling fish supply from capture fisheries (Ezenwa, 2004). This increase in acceptance could also be due to the growing demand for some fresh and brackish water fish species for the supply of valuable fish protein (Akinrotimi et al., 2007).

Rivers state being a maritime state with access to the sea, the state is endowed with some major inland water bodies and their valuable resources which could be harnessed to augment capture fisheries production. The fish farmers cannot meet the fish demand of the people and that makes fish to be very expensive which also make the fish to be food for the rich. The population of the state is increasing daily and fish demand is also increasing, but the production is still low, thus a lacuna exist which this research intends to fill (Pepple and Ebonwu, 2004). The objective of this study is to survey the status of fishing in Rivers State. With the aim of ascertaining the socioeconomic characteristics of the fish farmers; the production level of fish farmers, fish farming management practices; and determine the constraints to fish farming in the study area. 


\section{Materials and Methods}

Area of Study: This study was carried out in Rivers State of Nigeria. The state is bounded on the south by Atlantic Ocean, on the north by Anambra state, Imo and Abia states, on the east by Akwa Ibom state and the west by Bayelsa and Delta states Rivers State which is in the Niger Delta has topography of flat plans with a network of Rivers and tributaries. These include new Calabar, Orashi, Bonny, Sombre and Bartholomew Rivers. Rivers State lies between latitude five $5^{\circ} \mathrm{N}^{\prime}$ north and midway between longitude $5^{\circ} \mathrm{S}^{\prime}$ south of the Greenwich Meridian (Howard, 2007). The state is divided into 3 agricultural zones as shown in table 1 according to the Agricultural zoning system of Rivers State Agricultural Development Project (RISADP). The 3 zones are made up of 23 LGAs (local government areas) of Rivers State and they are:

Table 1: Agricultural zones with their LGAs.

\begin{tabular}{c|c|l}
\hline SiN & Zones & Local Government Areas \\
1. & I & Port Harcourt, Obio/Akpor, Ikwerre, Emohua, Oyigbo, Eleme, Gokana, Khana, Tai, Okirika, Ogu/Gbolo. \\
2. & II & Abua/Odual. Degema, Akuku-Toru, Asari-Toru, Bonny, Andoni and Opobo/Nkoro \\
3. & III & Etche, Ahoada East, Ahoada West, Ogba/Egbema/Ndoni, Omuma. \\
\hline
\end{tabular}

Source: Howard (2007)

Sampling technique, sample size and data analysis: Random sampling techniques were employed in the selection of Table 1: Demographic characteristics of fish farmers $(n=90)$.

\begin{tabular}{|c|c|c|c|}
\hline Age of Respondents (years) & Frequency & Percent & Mean \\
\hline $21-30$ & 15 & 16.7 & \\
\hline $31-40$ & 21 & 23.3 & \\
\hline $41-50$ & 31 & 34.4 & 42.3 \\
\hline 50 and above & 23 & 25.6 & \\
\hline Total & 90 & 100.0 & \\
\hline \multicolumn{4}{|l|}{ Gender of respondents } \\
\hline Male & 58 & 64.4 & \\
\hline Female & 32 & 35.6 & \\
\hline Total & 90 & 100.0 & \\
\hline \multicolumn{4}{|l|}{ Marital status of respondents } \\
\hline Single & 26 & 28.9 & \\
\hline Married & 55 & 61.1 & \\
\hline Widowed & 9 & 10.0 & \\
\hline Tatal & 90 & 100.0 & \\
\hline \multicolumn{4}{|l|}{ Household size } \\
\hline $1-5$ persons & 27 & 30.0 & \\
\hline $6-10$ persons & 38 & 42.2 & 08.0 \\
\hline 11-15 person & 15 & 16.7 & \\
\hline $16-20$ persons & 10 & 11.1 & \\
\hline Total & 90 & 100.0 & \\
\hline \multicolumn{4}{|l|}{ Educational level } \\
\hline First School Leaving Certificale & 2 & 2.2 & \\
\hline SSCE & 31 & 34.4 & \\
\hline OND/NCE & 9 & 10.0 & \\
\hline HND/B.Sc. & 25 & 27.8 & \\
\hline M.Sc. & 13 & 14.4 & \\
\hline Ph.D. & 10 & 11.1 & \\
\hline Total & 90 & 100.0 & \\
\hline \multicolumn{4}{|l|}{ Primary occupation of respondents } \\
\hline Full-time farming & 39 & 43.3 & \\
\hline Farming/Business & 28 & 31.1 & \\
\hline FarmeriCivil senant & 16 & 17.8 & \\
\hline Retired civil servantifarmer & 7 & 7.8 & \\
\hline Total & 90 & 100.0 & \\
\hline \multicolumn{4}{|l|}{ Farming experience (in years) } \\
\hline $1-5$ & 23 & 25.6 & \\
\hline $6-10$ & 42 & 46.7 & \\
\hline $11-15$ & 11 & 12.2 & \\
\hline $16-20$ & 14 & 15.6 & \\
\hline Total & 90 & 100.0 & \\
\hline \multicolumn{4}{|l|}{ Land ownership } \\
\hline Inherited & 71 & 78.9 & \\
\hline Leased/rent & 5 & 5.6 & \\
\hline Share cropping & 7 & 7.8 & \\
\hline Purchased & 7 & 7.8 & \\
\hline Total & 90 & 100.0 & \\
\hline \multicolumn{4}{|l|}{ Annual income from fish sales } \\
\hline$<N 100,000$ & 18 & 20.0 & \\
\hline$N_{100,000-N 200,000}$ & 28 & 31.1 & \\
\hline $\mathrm{N} 201,000-\mathrm{N} 300,000$ & 20 & 22.2 & \\
\hline$N 301,000-N 400,000$ & 19 & 21.1 & \\
\hline Above N501,000 & 5 & 5.6 & \\
\hline Total & 90 & 100.0 & \\
\hline
\end{tabular}
the samples from Agricultural Zones of Agricultural Development Programme of Rivers State. In zone I, 3 local government areas were selected; they are Ikwerre, Obio/Akpor and Tai. In zone II 3 local government areas were selected; they are Akuku-Toru, AsariToru, Abua/Odual. In zone III, Etche, Ogba/Egbema/ Ndoni and Omuma were also selected. In this 9 local government areas selected, 10 fish farmers were randomly selected from each local government making a total of 90 fish farmers. Data were collected by use of primary and secondary sources. Primary data were col. lected by use of interview schedule while secondary sources were by use of texibook, journal publication on aquaculture, and the internet. Structured interview schedule were used to collect data from the fish farmers. Data from the study were analyzed by use of deseriptive statistics (FAO, 2005).

\section{Results and Discussion}

Sociseconomic characteristics of fish farmers are shown in Table 1. majority $(34.4 \%)$ of the fish farmers werc between the age range of 4150 years, $25.6 \%$ were above 50 years, while $23.3 \%$ were between 31-40 years. The mean age is 42.3 which showed that the farmers are relatively young. The implication is that since the farmers are young, they are productive and innovative and can take risk in investments. This is in agreement with the results of Bolorundiro (2003) who observed same in fish farmers in Niger state, he reported that the age group 41-50 is the most active productive years of farmers. Also on the issue of gender majority ( $64.4 \%)$ of the respondents were males, while $35.6 \%$ were females. The implication is that male dominated fish farming in the study area. This is in agreement with Olawoye (2001) who noted that majority of fish farmers were males in his evaluation of the aquaculture status in Oyo state. Moreover, the marital status of the respondent showed that majority $(61.1 \%)$ of the fish farmers were married while $28.9 \%$ were single. The implication is that fish farming is the business of the married in the study area. This is in agrees with the findings of Ifejika and Ayanda (2005) who reported same in fish farmers in Kainji lake ba$\sin$ of Nigeria.

$\mathrm{T} h \mathrm{e}$

household size (Table 1) indicated that majority $(42.2 \%)$ of the respondents had a houschold size of 6-10 per-
Table 2: Sysiem of fish farming practice $(n=90)$

\begin{tabular}{lcc}
\hline \multicolumn{1}{c}{ System of fish farming practice } & Frequency & Percent \\
\hline Pond culture (earthen) & 21 & 23.3 \\
Cage culture & 13 & 14.4 \\
Concrete & 28 & 31.1 \\
Homestead & 20 & 22.2 \\
Pen culture & 8 & 8.9 \\
Total & 90 & 100.0 \\
\hline
\end{tabular}

Source: Field Survey, 2010 
sans while $30 \%$ had 1-5 persons. The mean household was 8.0 which indicated large family sizc. The implication of this finding is that there are two many people to feed even though they provide enough labour. In terms of educational level, majority $(34.4 \%)$ of the respondents were school certificate holders while $27.8 \%$ were HND/B.Sc holders, $14.4 \%$ were M.Sc holders. The implication of this finding is that most of the fish farmers in the study area are educated people that can easily adopt innovations. This is in agreement with the report of Ajana (1995) in survey of status of the fish farming in Ogun state. The primary occupation of the respondent revealed that majority $(43.3 \%)$ of the fish farmers in the study area were full-time farmers, $31.1 \%$ were farmers/business, while $17.8 \%$ were farmers/civil servants. This implies that most of the fish farmers devote their time in farming business. This disagree with that of Ifejika and Ayanda (2005) in Niger state who reported that involvement of most fish farmers in the state are on part-time basis. The farming experience revealed that majority (46.7\%) of the fish farmers had 6-10 years of experience in fish farming business, while $25.6 \%$ of fish farmers had $1-5$ years of experience, then $15.6 \%$ of the fish farmers had 16-20 years of experience. The implication of this finding is that most of the fish farmers in the study area are experienced which encourages increased production and innovation adoption. This is in agreement with that of Akinrotimi et al. (2010) in survey of brackish water aquaculture status in Rivers state. Land ownership revealed that majority (78.9\%) of fish farmers in the study area were the rightful owners of their land, while $7.8 \%$ of the fish farmers in the study areas were share croppers and purchased their land respectively. This implies that land acquisition for establishment of fish farm is not really their major problem which also encourages them in the fish farming. The annual income revealed that majority (31.1\%) of the fish farmers earned $\$ 100.00 \quad \$ 200.00$ annually, $22.2 \%$ of fish farmers carned $\$ 201,000 \quad \$ 300.000$, while $21.1 \%$ of the farmers earned $\mathrm{N} 301,000-\mathrm{N} 400,000$. The implication of this finding is that fish farming in the study area is a lucrative business. This is in disagreement with the report of Ifejika and Ayanda (2005).

Table 2 indicates that majority $(31.1 \%)$ of the fish farmers practice concrete fish pond, $23.3 \%$ practice pond culture (earthen fish pond), while $22.2 \%$ practice homestead in fish production. The implication is that fish farmers in the study area are relatively rich since they can afford concrete fish pond. This is in agreement with the report of Ajana (1995) who reported similar trend in Ogun state, Nigeria.

The mean annual production is indicated in Table 3, Clarias $12,000 \mathrm{mt}$, at unit cost of $\$ 500 / \mathrm{kg}$, Tilapia spp. $9,600 \mathrm{mt}$ with unit cost of $\mathrm{N} 500 / \mathrm{kg}$, hybrid of Clarias and Heterobranchus $8,500 \mathrm{mt}$ with unit cost of $\mathrm{N} 600 / \mathrm{kg}$ and common carp $5,000 \mathrm{mt}$ with unit cost of $\mathrm{N} 800 / \mathrm{kg}$. The total mean annual productions of fishes were 41,000 metric tons.

Data in table 4 showed that $38.9 \%$ of the fish farmers practice integrated fish farming that is combination of fish production with crops and animals. Also $26.7 \%$ of the farmers practice only monoculture, while $22.2 \%$ practice polyculture. The results obtained in this study revealed that majority $(72.2 \%)$ of the farmers practice only fisheries production, while $27.8 \%$ practice fisheries/crops and vegetable production, $6.7 \%$ practice fisheries/poultry, $2.2 \%$ practice fisheries/piggery and fisheries/ snailery respectively (Table 5), this is in tandem with is in agreement with that of Ajana (1995).

Table 3: Estimated Annual production capacity of table size fish and current price for various species $(n=90)$

\begin{tabular}{l|c|c|}
\hline \multicolumn{1}{c|}{ Types/species } & $\begin{array}{c}\text { Mean annual } \\
\text { (mt) } \\
\text { production }\end{array}$ & $\begin{array}{c}\text { Unit } \\
\text { cost } \\
(\mathrm{N})\end{array}$ \\
\hline Clarias & 12,000 & $500 / \mathrm{Kg}$ \\
\hline Heterobranchus & 6,000 & $600 / \mathrm{Kg}$ \\
\hline Hybrid of Clarias and Heterobranchus & 8,500 & $500 / \mathrm{Kg}$ \\
\hline Common carp & 5,000 & $800 / \mathrm{Kg}$ \\
\hline Tilapia species & 9,600 & $300 \mathrm{Kg}$ \\
\hline Tolal & 41,100 & \\
\hline
\end{tabular}

Table 5: Integrated fish farming activities $(n=90)$

\begin{tabular}{l|c|c}
\hline Integrated fish farming activities & Frequency & $\%$ \\
\hline Fisheries/crops \& vegetables & 15 & 16.7 \\
\hline Fisheries/poultry & 6 & 6.7 \\
\hline Fisheries/piggery & 2 & 2.2 \\
\hline Fisheries/snailery & 2 & 2.2 \\
Fisheries only & 65 & 72.2 \\
\hline Total & 90 & 100.0 \\
\hline
\end{tabular}

Table 7: Sources of water supply $(n=90)$

\begin{tabular}{lcc}
\hline \multicolumn{1}{c}{ Sources of water supply } & Frequency & $\%$ \\
\hline Rain water & 6 & 6.7 \\
Stream & 22 & 24.4 \\
Borehole & 36 & 40.0 \\
Well & 17 & 18.9 \\
Rivers (tide) & 9 & 10.0 \\
\hline
\end{tabular}

Table 4: Fish farming techniques/practice used by farmers $(n=90)$

\begin{tabular}{l|c|c}
\hline \multicolumn{1}{c}{ Fish farming technique/practice } & Frequency & $\%$ \\
\hline Monoculture & 24 & 26.7 \\
Polyculture & 20 & 22.2 \\
Integrated & 35 & 38.9 \\
Water recycle system & 11 & 12.2 \\
Total & 90 & 100.0 \\
\hline
\end{tabular}

Table 6: Sources of information for fish farmers $(n=90)$

\begin{tabular}{lcc}
\hline Sources of information for fish farmers & Frequency & $\%$ \\
\hline Extension agents & 16 & 17.8 \\
\hline Friends/fellow farmers & 53 & 58.9 \\
Mass media & 13 & 14.4 \\
Literature & 5 & 5.6 \\
Internet & 3 & 3.3 \\
\hline Total & 90 & 100.0 \\
\hline
\end{tabular}

Table 8: Types/species of fingerlings used by farmers $(n=90)$

\begin{tabular}{lcc}
\hline Types / species of fingerlings used & Frequency & $\%$ \\
\hline Clarias & 18 & 20.0 \\
Heterobranchus & 18 & 20.0 \\
Hybrid of Clarias and Heterobranchus & 19 & 21.1 \\
Common carp & 3 & 3.3 \\
Tilapia & 32 & 35.6 \\
Total & 90 & 100.0 \\
\hline
\end{tabular}

Source: Field Survey, 2010 
Regarding information on aquaculture practice, majority (58.9\%) of the respondents sourced their information fro friends/fellow farmers, $17.8 \%$ sourced their information from extension agents while $14.4 \%$ sourced their information fisheries production from mass media. Also, $3.3 \%$ of the farmers got their information from internet (Table 6 ). This support: the view of Olagunju et al. (2007) among fish farmers in Oyo and shows the literacy level of the fish farmers.

Table 9: Source of fingerlings $(n=90)$

\begin{tabular}{l|c|c}
\hline \multicolumn{1}{c|}{ Sources of fingerlings } & Frequency & $\%$ \\
\hline Personal hatchery & 29 & 32.2 \\
Government hatchery & 35 & 38.9 \\
Private hatchery & 17 & 18.9 \\
Wild & 9 & 10.0 \\
\hline Total & 90 & 100.0 \\
\hline
\end{tabular}

Table 7 revealed that majority $(40.0 \%)$ of the respondent sourced their water supply from Borehole, while $24.4 \%$ sourced thei water supply from streams, $18.9 \%$ sourced their water from well, thi results is in line with that of Ogunlade (2007) in survey of fish farming activities in Osun state. This implies that most of the farmers are using borchole as their sources of water supply followed by farmers usin stream as their sources of water supply.

Table 8 indicated that majority $(35.6 \%)$ of fish farmers use Tila pia species as their fingerlings, $21.1 \%$ use hybrid of Clarias and Het erobranchus and $20.0 \%$ use Clarias and Heterobranchus species respectively. Table 9 indicated that majority (38.9\%) of the fish farmers sourced their fingerlings from government hatchery $32.2 \%$ of the fish farmers got their fingerlings from persona hatchery, and $18.9 \%$ of fish farmers got their fingerlings from private hatchery. This implies that most of the fish farmers do not have hatchery in their farms. They normally get it from outside their farms.

Table 10 reveals that majority $(92.6 \%)$ of the farmers indicated that

Table 10: Constraints to Fish Farming in the Study Area $(n=90)$

\begin{tabular}{l|l|c}
\hline No. & \multicolumn{1}{|c|}{ Constraints } & Percentage \\
\hline 1. & Inadequate infrastructure & 52.6 \\
\hline 2. & Inadequate supply fish feeds & 70.8 \\
\hline 3. & Irregular electricity supply & 92.6 \\
\hline 4. & Poor finance & 85.8 \\
5. & Poor hatchery facilities & 51.2 \\
\hline 6. & High cost of feeds & 70.8 \\
\hline 7. & Suitable land acquisition & 60.2 \\
\hline 8. & High price of input & 80.5 \\
\hline 9. & Diseases and poaching & 86.7 \\
\hline 10. & Irregular water supply & 85.6 \\
\hline 11. & Poor water quality & 40.2 \\
\hline 12. & High cost of management & 60.8 \\
\hline 13. & Poor extension services & 55.8 \\
\hline 14. & Poor marketing & 60.5 \\
\hline 15. & Inadequate skill workers & 48.4 \\
\hline 16. & Cannibalism & 90.5 \\
\hline
\end{tabular}

Source: Field Survey 2010

irregular electricity supply is a major constraint to fish production in tha study area. However, the following factors affect fish farming in the study area, cannibalism $(90.5 \%)$ diseases and poaching $(86.7 \%)$, poor finance $(85.5 \%)$, irregular water supply $(85.6 \%)$, high cost of inputs $(80.5 \%)$, high cost of feeds $(70.8 \%)$, inadequate supply of feeds $(70.8 \%)$ and inadequate supply of fish feeds $(70.5 \%)$

The implication of this finding is that almost all the factors indicated are impediment to fish production in the study area. This is in agreement with Chua-Thia (2009).

\section{Conclusion}

The status of aquaculture in Rivers State indicated that its potential in increasing fish production is yet to be fully utilized, as a result of factor limiting its expansion. Therefore contributions of stakeholder in the industry such as farmers, cooperative societies, research agencies are appropriate government interventions are urgently needed to assist production of fish in the state and create an enabling environment for aquaculture, which will ultimately results in the sustainable growth of fish farming in Rivers State. In order to facilitate the efficient operation of the fish farming in the state, immediate action would be required in the following areas: Provision of assistance in aquaculture feasibility survey and identification'selection of suitable sites for fish farm development. Also technical advice on pond construction and preparation, species selection and supply for stocking purposes, fish pond management practices in terms of feeding, fertilization, harvesting, preservation and marketing of fish harvest should be made available to farmers. Conclusively, formation of fish farming association and cooperative societies for opportunities to credit facilities is crucial for the growth and sustainability of aquaculture in the state.

\section{REFERENCES}

Ajana, A.M. (1995). A diagnostic survey of the status of Aquaculturc (fish farming) in Ogun State. A Refils Project of the National Agricultural Research Project (NARP).

Akinrotimi, O.A., Onunkwo, D.N., Cliffe, P.T., Anyanwu, P.T. and Orokotan, O.O. (2007). The role of fish in the nutrition and livelihood of families in Niger Delta, Nigeria. International Journal of $\Lambda$ gric Systems. Vol. 41:344-356.

Edun, O.M., Uka, A., Oguri, K.T., Mokayi, P.K. and Owhonda, K.N. (2010). Public perception of mudskipper consumption in some fishing communities of Rivers State. In Ansa E.J., Fushina-Bombata, H.A. and Vdimele, P.E. (eds). Proceedings, 25th FISON Annual Conference, October. Badagry, Lagos

Anyanwu, I. E., Gabriel, U.U., Akinrotimi, O.A., Bekibele, D.O. and Onunkwo, D.N. (2007). Brackish water aquaculture a veritable tool for the empowerment of Viger Delta Communitics. Seientific Research and Essay. 2/8:295-301.

Bolorunduro, P.I. (2003). Improved fishcries technology and approaches for dissemination: A case study for Niger State. In: Eyo, A.A. and Ajao, E.A. (eds). Proceedings, 6th FISON Annual Conference, Maiduguri Nov. 4-9. 74-79

Chua-Thia, E.G. (2009). An Overview of the fisheries and Aquaculture Industries in Asia. Production of the 1st Asia fusheries forum. Manilla, Philippines. 26-31 May, 1986. 
Ezenwa, B.1.O. (2004). Aquaculture Development Research in Nigeria, 41-80. In Aquaculture Development and Research in Sub-Sahara Africa FAO 1994 edited by G. Cohe. CIFA Tech. pap.23.

FAO (2005). The state of world fisheries aquaculture: nbjective and reliable fishery status and trends reporting. 1-3. Retrieved from http: $/ i$ Www.fao.org//DOCREP/003/X800ZE/ $800 \mathrm{ze} 04 / \mathrm{htm}$. Accessed $9 / 13 / 2005$.

Howard, K.T. (2007). An assessment of aquaculture subsector in the states of Rivers, Ondo and Lagos, Nigeria. World Bank Repori.

Ifejika, P.I. and Ayanda, J.O. (2005). Status of fisherics aquaculture in Kainji lake basin of Nigeria. Proceedings, 20th FISON Annual Conference. Port Harcourt, 14-18th Nov., 2005. 281-286.

Olagunji, F.I., Adesiyan, I.O. and E«ekicl, A.A. (2007). Economic viability of catfish production in Oyo State. J. Him Ecol. 21/2:121124.

Olawoye, J. (2001). Contemporary rescarch and problem areas in agricultural extension and rural development. The Ihadan Extension Monograph series. No. 2. Dept. of Agricultural extension and rural development. University of Ibadun. Nigcria. 17-20.

Ogunlade, 1. (2007). Background Fish Farmers Information needs on Osun Stutc. AAAE Ghana Canference Proceeding. 165 - 169.

Pepple and Ebonwu (2001). A review of fishes development in Nigeria, 2001 China-Africa Technical Cooperation among Developing

Countries (TCDC), International Training Course on Integrated fish farming, Wuki, China, A pril 25 th to July 23rd 2003. 22.

Satia, B.P. (1990). National Review for Aquaculture Development in A frica. Nigeria FAO fisheries circular. No. $770,29$.

New Partnership for Africa's Development (NEPAD) (2005). "Fish for All" Summit. The NEPAD Action Plan for the Development of Afican fisheries and the aquaculture August $23 \mathrm{rd}$, Abuja Nigeria.

Wokoma, S.A. (1986). Conmercial pond fish culture. In (FISON) (onference Proceedings. Pp: 377- 391. 